\title{
ОСОБЛИВОСТІ ПОЗИЦІОНУВАННЯ НА РИНКУ РЕСТОРАНІВ ШВИДКОГО ОБСЛУГОВУВАННЯ
}

\author{
ОСОБЕННОСТИ ПОЗИЦИОНИРОВАНИЯ НА РЫНКЕ РЕСТОРАНОВ \\ БЫСТРОГО ОБСЛУЖИВАНИЯ
PECULIARITIES OF POSITIONING ON FAST FOOD RESTAURANTS MARKET

Стаття фокусує увагу на важливості позиціонування в ресторанному бізнесі. В статті розроблено адаптовану до ринку ресторанів швидкого обслуговування методику позиціонування. Запропонована методика складається з чотирьох етапів: інформаційного, дослідницького, аналітичного та імплементаиійного. На першому етапі проводяться кабінетні дослідження, при иььому основана увага приділяється вивченню особливостей поведінки споживачів, структури конкуренції, специфіка послуги харчування. Основними завданнями другого етапу є збір даних щуодо попередньо відібраних параметрів послуги та конкурентів в результаті опитування спожсивачів. На третьому етапі основними завданнями є побудова карт сприйняття та їх аналіз. статистична обробка отриманих даних, перетворення їх в інформачію. На останньому етапі розробляється стратегія $i$ тактика позиціонування. В статті наведено приклад розроблення стратегї $і$ тактики позиціонування одного з операторів ринку ресторанів швидкого обслуговування міста Києва із використанням наведеної методики.

Ключові слова: ресторанний бізнес, ресторани швидкого обслуговування, позиціонування, параметри позиціонування, карти сприйняття, стратегія позиціонування, тактика позиціонування.

Статья фокусирует внимание на важности позиционирования в ресторанном бизнесе. B статье разработана адаптированная $\kappa$ рынку ресторанов быстрого обслуживания методика позиџионирования. Предложенная методика состоит из четырех этапов: информачионного, исследовательского, аналитического и имплементационного. На первом этапе проводятся кабинетные исследования, при этом основное внимание уделяется изучению особенностей поведения потребителей, структуре конкуренции, специфике услуг питания. Основными задачами второго этапа являются: сбор данных по предварительно отобранным параметрам услуг и конкурентам в результате опроса потребителей. На третьем этапе основными задачами являются: построение карт восприятия и их анализ, статистическая обработка полученных данных, преобразование их в информацию. На последнем этапе разрабатывается стратегия и тактика позиционирования. В статье приведен пример разработки стратегии и тактики позиционирования для одного из операторов рынка ресторанов быстрого обслуживания города Киева с использованием предложенной методики. 
Ключевые слова: ресторанный бизнес, рестораны быстрого обслуживания, позиционирование, параметры позиционирования, карты восприятия, стратегия позиционирования, тактика позиционирования.

The article focuses on the importance of positioning in the restaurant business. Customized to fast food market restaurants method of positioning is developed in the article. The proposed method consists of four stages: information, research, analytical and the implementation. At the first stage the desk research have place with emphasis based study of the behavior of consumers, competition structure, specific of fast food services. The main objectives of the second phase is to collect data on pre-selected parameters of services and competitors as a result of consumer surveys. In the third stage the main tasks is to build maps of perception and analysis, statistical data processing, transforming them into information. At the last stage a strategy and tactics of positioning have to be developed. The article gives examplee of development strategies and tactics positioning for one of the operators of fast food restaurants in Kyiv using the reduced method.

Keywords: restaurants, fast food restaurants, positioning, parameters of positioning, maps of perception, positioning strategy, tactics of positioning.

Вступ. Сучасною світовою тенденцією є підвищення значення сфери послуг, як в світовій економіці, так і в економіці окремих країн і України зокрема. В свою чергу це призводить до природної активізації маркетингових зусиль в даному секторі. Треба зазначити, що сам ринок послуг має свою специфіку та складності, що вимагають додаткових досліджень та розроблення на їх основі нових ефективних інструментів маркетингового впливу.

Ресторанний бізнес є типовим представником сфери послуг, при цьому він сам по собі є достатньо динамічним і многогранним. На даному ринку достатньо швидко з'являються нові концепції та формати ресторанів. Останнім часом в Україні спостерігається зростання популярності закладів швидкого харчування, що зумовлено низкою економічних, демографічних, та соціокультурних факторів.

Взагалі в Україні ресторанний бізнес є достатньо прибутковим, тому на ринку має місце стабільне зростання конкуренції. При цьому зростає не тільки ринок послуг, але й вимоги до нього з боку відвідувачів - вони стали більш вибагливими до сервісу, дизайну, кухні, внутрішньої атмосфери. За таких умов суттєвої актуальності набувають такі маркетингові інструменти як маркетингові дослідження, сегментація та позиціонування. Проте, треба зазначити, що в більшості випадків оператори даного ринку не мають формалізованої маркетингової стратегії, і використовують реактивний підхід до маркетингових досліджень.

Проблемами ринкового позиціонування на споживчому ринку займалися такі автори як А. Райс, Дж. Траут[1, 3], Г. Дж. Холлі, Н.Ф. Персі, Дж. Сандерс [2], С. Рівкін [3], С.Х. Уокер [4] Ф. Котлер [5], Д. Аакер [6], О.В. Зозульов [7, 8], Н.Л. Пісаренко [8]. В роботах зазначених авторів 
висвітлені базові теоретичні положення, визначні стратегеї ринкового позиціонування. Проте, такий специфічний ринок послуг як ресторанний бізнес потребує певної адаптації теоретичних положень, що i буде запропоновано в даній статті.

Постановка завдання. Основною метою дослідження є розроблення адаптованої до ринку ресторанів швидкого обслуговування методики позиціонування. Апробація іï на практиці одного з мережевих операторів ринку в результаті якої можливим стає розроблення стратегії та тактики позиціонування.

Методологія. Методологічною базою дослідження слугували фундаментальні положення економічної теорії, менеджменту та маркетингу. В роботі було використано такі загальнонаукові методи дослідження, як порівняння, узагальнення, аналіз та синтез. Для обробки даних маркетингового дослідження було використано статистичний пакет SPSS та табличний процесор MS Excel. Застосовано табличні та графічні економікостатистичні методи.

Результати дослідження. На першому етапі процесу позиціонування збирається максимум необхідної інформації, що може бути отримана в рамках кабінетних досліджень. Аналізуються фактори маркетингового середовища, збирається вторинна інформація. В результаті визначаються параметри позиціонування торговельної марки та відбираються найбільш небезпечні конкуренти для подальшого аналізу карт сприйняття. Особливої уваги слід приділити специфіці ринку послуг харчування обумовленій наступними факторами:

1. особливість поведінки споживачів;

2. структура конкуренції;

3. специфіка послуги харчування.

1. Щодо особливості поведінки споживачів, то тут треба відзначити, що найбільшою популярністю користується харчування під час обіду. Меншою $є$ кількість, клієнтів, які користуються послугами ресторанів швидкого обслуговування у вечірній час. Зовсім невелика кількість споживачів відвідують закладі з ранку. При цьому треба відмітити, що суттєво відрізняється структура продажів ресторанів за асортиментними позиціями в зазначених проміжках часу. В обід більше споживається страв 3 основного меню, у вечорі зростають обсяги споживання алкоголю, з ранки більше споживаються гарячі напої. Зазначені диспропорції протягом доби спостерігаються в більшому або в меншому ступені в залежності від того, де розташовується ресторан. Таким чином, з точки зору роботи 3 клієнтами всі ресторани умовно розділяють на три категорії:

ресторани, орієнтовані на потік (розташовуються на ринках, торговельних супермаркетах, біля станцій метро); 
- ресторани, орієнтовані на стандарти в обслуговувані (розташовуються в торговельно-розважальних центрах);

- ресторани, орієнтовані на постійного клієнта (переважно розташовуються в бізнес-центрах та неподалік від них).

В таблиці 1 наведено детальний опис існуючих сегментів ринку ресторанів швидкого обслуговування 3 якими працює мережа «Домашні страви».

Таблиця 1

Опис ринкових сегментів «Домашні страви»

[розроблено автором]

\begin{tabular}{|c|c|c|c|}
\hline \multirow{2}{*}{$\begin{array}{l}\text { Профіль } \\
\text { ринкового } \\
\text { сегмента }\end{array}$} & \multirow[t]{2}{*}{ Психологічний портрет } & \multicolumn{2}{|c|}{ Специфіка комплексу маркетингу } \\
\hline & & Елемент & Відмінності \\
\hline $\begin{array}{l}\text { 1. Офісні } \\
\text { працівники }\end{array}$ & $\begin{array}{l}\text { Це працівники, які працюють } \\
\text { у тому ж самому бізнес } \\
\text { центрі, у якому розміщений } \\
\text { заклад, або ті, які працюють } \\
\text { неподалік. }\end{array}$ & $\begin{array}{l}\text { Product } \\
\text { Process } \\
\text { Price } \\
\text { Promotion } \\
\text { Physical } \\
\text { evidence }\end{array}$ & $\begin{array}{l}\text { Для них важливим } є \text { наявність } \\
\text { кількох видів ланчу за } \\
\text { доступною ціною; відсутність } \\
\text { черги у зв'язку } 3 \text { обмеженою } \\
\text { кількістю часу, що відводиться } \\
\text { на перерву; затишна атмосфера, } \\
\text { яка дозволятиме відволіктись від } \\
\text { негайних справ у офісі;аудіо або } \\
\text { відео супровід; наявність знижок } \\
\text { і спеціальних пропозицій для } \\
\text { підвищення лояльності }\end{array}$ \\
\hline $\begin{array}{l}\text { 2. Офіси, які } \\
\text { забезпечу- } \\
\text { ють } \\
\text { харчуванням } \\
\text { своїх } \\
\text { працівників } \\
\end{array}$ & $\begin{array}{l}\text { Такі офіси займають } \\
\text { незначну частку, так як не } \\
\text { всі забезпечують } \\
\text { харчуванням своїх клієнтів; } \\
\text { можливе співпраця з іншими } \\
\text { закладами }\end{array}$ & \begin{tabular}{|l} 
Product \\
Price
\end{tabular} & $\begin{array}{l}\text { Важливим є комплексний обід за } \\
\text { доступною ціною; стабільне і } \\
\text { вчасне постачання замовлень }\end{array}$ \\
\hline $\begin{array}{l}\text { 3. Люди, які } \\
\text { спеціально } \\
\text { приїжджають }\end{array}$ & $\begin{array}{l}\text { Займають найменшу частку, } \\
\text { так як заклади знаходяться } \\
\text { не в «людних» місцях і це } \\
\text { заважає збільшенню } \\
\text { клієнтів; на них впливають } \\
\text { такі референтні групи як } \\
\text { знайомі, офісні працівники, } \\
\text { відвідувачі тренінгів }\end{array}$ & $\begin{array}{l}\text { Place } \\
\text { Promotion } \\
\text { Product } \\
\text { People } \\
\text { Process }\end{array}$ & $\begin{array}{l}\text { Для них є важливим наявність } \\
\text { покажчиків та реклами на } \\
\text { бігбордах про інформування } \\
\text { розміщення закладу, а також } \\
\text { розроблена програма } \\
\text { стимулювання клієнтів для } \\
\text { підвищення привабливості для } \\
\text { відвідування саме цього } \\
\text { закладу; статті в Інтернеті }\end{array}$ \\
\hline $\begin{array}{l}\text { Працівники } \\
\text { «МЕТRO } \\
\text { Cash \& } \\
\text { Carry»; }\end{array}$ & $\begin{array}{l}\text { Працюють в одному } \\
\text { приміщенні, де розміщений } \\
\text { заклад, мають обмежений } \\
\text { час на обід; надають } \\
\text { великого значення думці } \\
\text { інших співробітників про } \\
\text { заклад, який відвідують }\end{array}$ & $\begin{array}{l}\text { Product } \\
\text { Price } \\
\text { Process }\end{array}$ & $\begin{array}{l}\text { Важливим є широкий вибір їжі, } \\
\text { так як є постійними клієнтами; } \\
\text { доступна ціна, а також } \\
\text { швидкий процес замовлення }\end{array}$ \\
\hline
\end{tabular}




\begin{tabular}{|c|c|c|c|}
\hline \multirow{2}{*}{$\begin{array}{c}\text { Профіль } \\
\text { ринкового } \\
\text { сегмента }\end{array}$} & \multirow[t]{2}{*}{ Психологічний портрет } & \multicolumn{2}{|c|}{ Специфіка комплексу маркетингу } \\
\hline & & Елемент & Відмінності \\
\hline $\begin{array}{l}\text { Клієнти } \\
\text { «METRO } \\
\text { Cash \& } \\
\text { Carry»; }\end{array}$ & \begin{tabular}{|l|} 
Люди, які приїхали за \\
великою кількістю покупок; \\
часто стомлюються і \\
шукають заклад, де можна \\
відпочити і поїсти у цьому \\
ж приміщенні \\
\end{tabular} & $\begin{array}{l}\text { Place } \\
\text { Product } \\
\text { Physical } \\
\text { evidence } \\
\text { Promotion }\end{array}$ & $\begin{array}{l}\text { Для них є важливим місце } \\
\text { розташування, щоб зменшити } \\
\text { час на пересування і пошук } \\
\text { закладу; зручні місця для } \\
\text { споживання їжі; наявність } \\
\text { знижок та пропозицій }\end{array}$ \\
\hline
\end{tabular}

2. Щодо конкуренції на ринку, то треба зазначити, що тут присутні як великі мережеві оператори, так і по одиничні кафе, які пропонують в обідній час бізнес-ланчі. При цьому, важливе питання полягає у відборі найбільш небезпечних конкурентів в процесі позиціонування. Справа в тому, що великі мережеві оператори не так часто розташовуються один біля одного, таким чином рідко спостерігається пряма локальна конкуренція. В той час як дуже часто мережевому оператору доводиться конкурувати 3 невеличкими кафе, що знаходяться поруч. Тому з урахуванням зазначених особливостей пропонуються наступні рекомендації щодо відбору конкурентів під час позиціонування:

- $\quad$ врахування головних мережевих операторів;

- врахування територіального розташування схожих за масштабами діяльності мережевих операторів;

- $\quad$ врахування подальших планів розширення власної мережі;

- включення до переліку найбільш популярних кафе, що спричиняють локальну конкуренцію.

Таким чином, серед головних конкурентів закладів швидкого харчування мережі «Домашні страви», які буде відібрано в процесі позиціонування можна виділити:

Україні;

- Пузата хата - найбільша мереж ресторанів швидкого харчування в

- Два Гуся - мережа, заклади якої знаходяться найближче;

- $\quad$ кафе з бізнес ланчем яке знаходиться в безпосередній близькості.

Перш ніж перейти до відбору конкретних параметрів за якими будуть побудовані карти сприйняття розглянемо основні фактори конкурентоспроможності послуги швидкого харчування. Порівняльний аналіз за факторами конкурентоспроможності наведений таблиці 2.

1. Вартість - є обов’язковим фактором на будь-якому ринку, і щодо послуг ресторанів швидкого обслуговування пропонується починати порівняння конкурентів саме 3 неї.

2. Смак - є специфічним для ресторанного бізнесу параметром, адже значна кількість потенційних клієнтів обирає заклад для харчування саме за даним критерієм. 
3. Ситність - також є важливим специфічним для ринку фактором, для більшості споживачів саме втамування голоду $\epsilon$ основним мотивом відвідування закладів швидкого харчування.

4. Атмосфера закладу. Екстер'єр та інтер'єр закладів відіграє важливу роль, тому що відвідувачі завжди звертають увагу на оформлення, унікальність закладу, це $є$ вагомим фактором, який впливає на лояльність споживачів.

5. Наявність власної торгової марки є основою формування впізнання та відомості закладу.

6. Наявність мережі закладів дає можливість відвідувати улюблений заклад у багатьох районах i регіонах, наявність мережі впливає на відвідування так як підвищує приналежність до певного закладу.

7. Місце розташування закладів - важливий фактор, який значною мірою вливає на відвідування, це: центральні райони, в радіусі метро, ТЦ, ТРЦ, БЦ.

8. Асортимент страв має бути широким і різноманітним для задоволення потреб клієнтів.

9. Доставка дає можливість замовити улюблені страви, не відвідуючи заклад.

10. Дисконтна програма - підвищує лояльність споживачів, так як гарантується певна знижка при замовленні.

11. Рівень обізнаності. Якщо про заклад мало відомо клієнтам, то він не стає популярним і відповідно зменшуються прибутки.

12. Обслуговування є важливим фактором, тому що саме стимулювання підвищує кількість клієнтів і частоту відвідування.

13. Кейтерінг надає клієнту можливість святкувати події у обраному закладі, зробивши при цьому особисте замовлення, обрати меню.

Зважаючи на попередній аналіз сильних та слабких сторін за факторами конкурентоспроможності можна обрати 7 основних параметрів: асортимент; вартість; ситність; смак; атмосфера; обслуговування; зручність розташування. 
Таблиця 2

Аналіз сильних та слабких сторін фірми в порівнянні з конкурентами [за результатами проведенного дослідження]

\begin{tabular}{|c|c|c|c|c|c|c|c|c|}
\hline \multirow[t]{2}{*}{ № } & \multirow[t]{2}{*}{ Показники } & \multicolumn{7}{|c|}{$\begin{array}{c}\text { Рейтинг атрибутів послуг основних конкурентів у } \\
\text { порівнянні з Домашні страви }\end{array}$} \\
\hline & & -3 & -2 & -1 & 0 & 1 & 2 & 3 \\
\hline 1 & Вартість & & $\ldots . . .$. & r & & & & \\
\hline 2 & Смак & 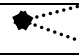 & & L & - & & & \\
\hline 3 & Ситність & & $\cdots$ & & & -1 & 9 & \\
\hline 4 & Атмосфера закладу & & & 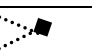 & & & & \\
\hline 5 & Торгова марка & & $\ldots$ & & & & & $\infty$ \\
\hline 6 & Наявність мережі закладів & $\cdots$ & . & & & & & \\
\hline 7 & Місце розташування закладів & & & & $\because$ & & & \\
\hline 8 & Асортимент страв & & 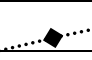 & & & & & \\
\hline 9 & Доставка & 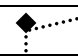 & & & & & & \\
\hline 10 & Дисконтна програма & $\therefore$ & & & & & & \\
\hline 11 & Рівень обізнаності & & & $\cdots \cdots$ & & & & \\
\hline 12 & Обслуговування & $+\cdots$ & & & & $\rightarrow$ & $=$ & \\
\hline 13 & Кейтерінг & - & & & & & & - \\
\hline
\end{tabular}

Пояснення до табл. 2:

Пузата Хата

Два Гуся

Кафе $з$ бізнес ланчем -

При визначенні параметрів позиціонування авторами пропонується враховувати важливість та вірогідність отримання переваги.

\section{2. Дослідницький етап.}

На другому етапі процесу позиціонування вирішуються дві задачі:

- збір даних щодо відібраних на попередньому етапі параметрів послуги та конкурентів в результаті опитування споживачів;

- статистична обробка отриманих даних, перетворення їх в інформацію.

Таким чином, для отримання інформації щодо сприйняття споживачами послуги ресторану швидкого обслуговування було проведено опитування споживачів. В рамках маркетингового дослідження споживчих мотивацій та іміджу торгової марки «Домашні страви» на ринку м. Києва для розроблення ефективного комплексу маркетингових комунікацій було включено блок пошукових питань, що стосуються позиціонування.

Генеральна сукупність - відвідувачі закладу, які працюють неподалік офісні працівники; відвідувачі проїздом; Одиниця дослідження - люди, які відвідують заклади мережі «Домашні страви». У зв'язку з тим, що заклади знаходяться у бізнес районах, то клієнтами переважно є офісні працівники. В результаті дослідження було опитано 150 респондентів. Методом комунікації під час проведення дослідження із кінцевими споживачами $\epsilon$ особисте 
інтерв'ю за допомогою спеціально розробленої анкети. Для отримання необхідної інформації було задане питання анкети з використанням бальних оцінок. Респондентам необхідно було оцінити за п'яти бальною шкалою відібрані параметри щодо позиціонування по кожному закладу із запропонованих. У процесі обробки даних для зручності, параметри розподілили по кожному закладу окремо, отримані наступні результати (табл. 3-6):

Таблиця 3

Сприйняття атрибутів якості послуги харчування в мережі «Домашні страви»

[за результатами проведенного дослідження]

\begin{tabular}{|l|l|l|l|l|l|l|l|l|}
\hline & 1 & 2 & 3 & 4 & 5 & Середнє & Мода & Всього \\
\hline Асортимент & 0 & 22 & 45 & 57 & 26 & 3,58 & 4 & 150 \\
\hline Вартість & 0 & 14 & 21 & 69 & 46 & 3,59 & 4 & 150 \\
\hline Смак & 0 & 8 & 12 & 44 & 86 & 4,39 & 5 & 150 \\
\hline Ситність & 0 & 2 & 14 & 43 & 91 & 4,14 & 5 & 150 \\
\hline Атмосфера & 9 & 15 & 25 & 58 & 43 & 3,74 & 4 & 150 \\
\hline Обслуговування & 5 & 18 & 28 & 57 & 42 & 3,75 & 4 & 150 \\
\hline $\begin{array}{l}\text { Зручність } \\
\text { розташування }\end{array}$ & 0 & 18 & 8 & 35 & 89 & 4,30 & 5 & 150 \\
\hline
\end{tabular}

Щодо відповідей споживачів відносно торговельної марки Домашні страми», то найвищі оцінки отримали такі параметри як смак, ситність та зручність розташування - 4,5; 4,4 та 4,3 бали відповідно.

Таблиця 4

Сприйняття атрибутів якості послуги харчування в мережі Пузата хата

\begin{tabular}{|l|l|l|l|l|l|l|l|l|}
\hline & [за результатами провенного досліджння] \\
\hline & 1 & 2 & 3 & 4 & 5 & Середне & Мода & Всього \\
\hline Асортимент & 0 & 0 & 21 & 81 & 48 & 4,18 & 4 & 150 \\
\hline Вартість & 3 & 9 & 38 & 54 & 46 & 3,87 & 4 & 150 \\
\hline Смак & 0 & 0 & 26 & 66 & 58 & 4,21 & 4 & 150 \\
\hline Ситність & 0 & 0 & 41 & 65 & 44 & 4,02 & 4 & 150 \\
\hline Атмосфера & 6 & 34 & 67 & 28 & 15 & 3,08 & 3 & 150 \\
\hline Обслуговування & 0 & 33 & 61 & 43 & 13 & 3,24 & 3 & 150 \\
\hline $\begin{array}{l}\text { Зручність } \\
\text { розташування }\end{array}$ & 0 & 24 & 76 & 28 & 22 & 3,32 & 3 & 150 \\
\hline
\end{tabular}

Щодо відповідей споживачів відносно торговельної марки Пузата хата, то найвищі оцінки отримали такі параметри як асортимент, ситність, смак 4,2; 4,2 та 4,0 бали відповідно. 
Таблиця 5

Сприйняття атрибутів якості послуги харчування в мережі Два Гуся [за результатами проведенного дослідження]

\begin{tabular}{|l|l|l|l|l|l|l|l|l|}
\hline & 1 & 2 & 3 & 4 & 5 & Середнє & Мода & Всього \\
\hline Асортимент & 0 & 22 & 45 & 57 & 26 & 3,58 & 4 & 150 \\
\hline Вартість & 14 & 58 & 37 & 16 & 25 & 2,87 & 2 & 150 \\
\hline Смак & 0 & 8 & 12 & 56 & 74 & 4,31 & 5 & 150 \\
\hline Ситність & 4 & 5 & 32 & 34 & 75 & 4,40 & 5 & 150 \\
\hline Атмосфера & 9 & 15 & 25 & 58 & 43 & 3,74 & 4 & 150 \\
\hline Обслуговування & 5 & 13 & 44 & 52 & 46 & 3,76 & 4 & 150 \\
\hline $\begin{array}{l}\text { Зручність } \\
\text { розташування }\end{array}$ & 0 & 18 & 33 & 64 & 35 & 3,77 & 4 & 150 \\
\hline
\end{tabular}

Щодо відповідей споживачів відносно торговельної марки Два гуся, то найвищі оцінки отримали такі параметри як, ситність та смак - 4,3; 4,1 бали відповідно.

Таблиця 6

Сприйняття атрибутів якості послуги харчування у кафе з бізнес ланчем

\begin{tabular}{|l|l|l|l|l|l|c|l|l|}
\hline & [за результатами провденного дослідження] \\
\hline Асортимент & 1 & 2 & 3 & 4 & 5 & Середне & Мода & Всього \\
\hline Вартість & 0 & 37 & 87 & 26 & 0 & 2,93 & 3 & 150 \\
\hline Смак & 6 & 53 & 67 & 24 & 0 & 2,73 & 3 & 150 \\
\hline Ситність & 0 & 4 & 48 & 69 & 29 & 3,82 & 4 & 150 \\
\hline Атмосфера & 0 & 8 & 84 & 45 & 13 & 3,42 & 3 & 150 \\
\hline Обслуговування & 9 & 28 & 54 & 39 & 20 & 3,22 & 3 & 150 \\
\hline $\begin{array}{l}\text { Зручність } \\
\text { розташування }\end{array}$ & 0 & 8 & 19 & 77 & 46 & 4,07 & 4 & 150 \\
\hline
\end{tabular}

Щодо відповідей споживачів відносно кафе з бізнес ланчем, то найвищі оцінки отримали такі параметри як зручність розташування, ситність $-4,1 ; 3,8$ бали відповідно.

Таблиці, які наведені вище, слугуватимуть джерелом для побудови карт сприйняття, що дозволить проаналізувати ключові параметри позиціонування на наступному етапі.

\section{3. Аналітичний етап.}

На третьому етапі процесу позиціонування згідно запропонованої методики вирішуються наступні завдання:

- $\quad$ побудова карт сприйняття;

- $\quad$ аналіз карт сприйняття.

Таким чином, наступне завдання в процесі позиціонування торговельної марки «Домашні страви» полягає у побудові карт сприйняття споживачами визначених вище атрибутів послуг конкуруючих компаній. Для побудови карт 
сприйняття за вертикальну вісь було взято критерій «вартість», за горизонтальну інші параметри (Рис. 1-6). Чим більша оцінка, тим краще відвідувачі сприймають послугу компанії за визначеними атрибутами.

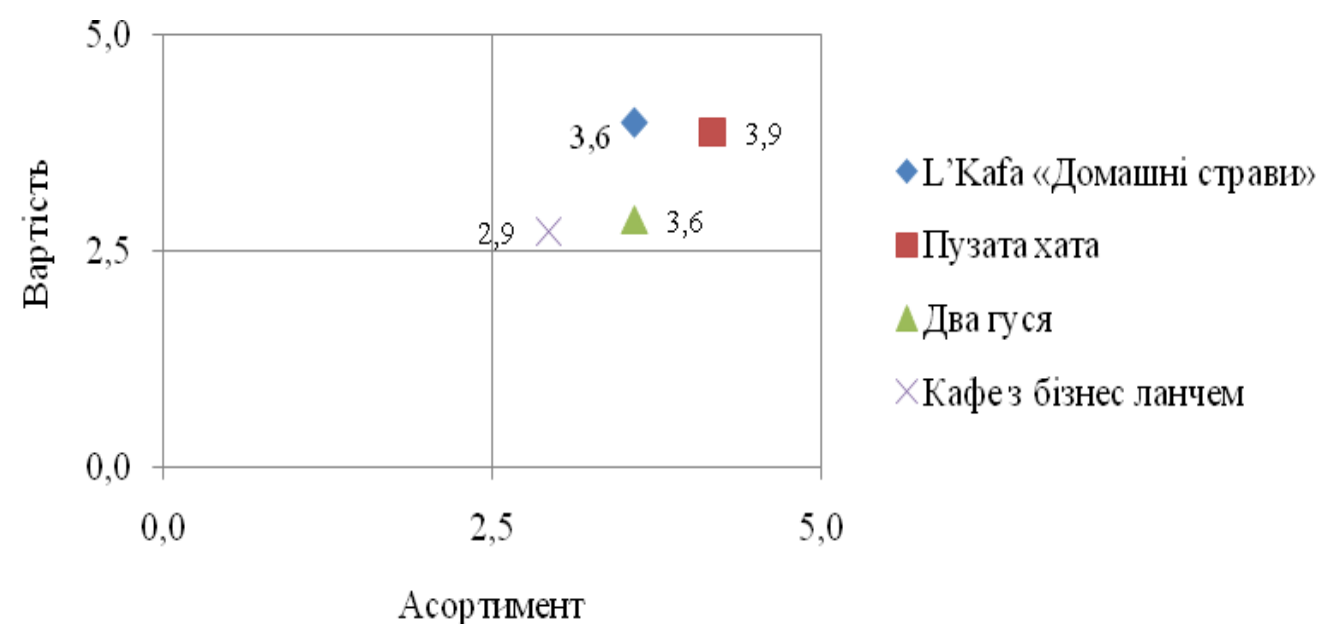

Рис. 1. Карта сприйняття «вартість і асортимент»

На рисунку 3.6 зображена залежність вартості і асортименту. На думку відвідувачів, вартість найкраща у «Домашні страви», так як середній бал склав 4,0, у «Пузата хата» - 3,9, у «Два гуся» - 2,9 і у кафе з бізнес ланчем найгірше - 2,1. Проте асортимент сприймають краще у «Пузата хата»і - 4,2, «Домашні страви» і «Два гуся» - 3,6, і - у кафе з бізнес ланчем - 2,9.

На рис. 2 зображено залежність вартості і ситності.

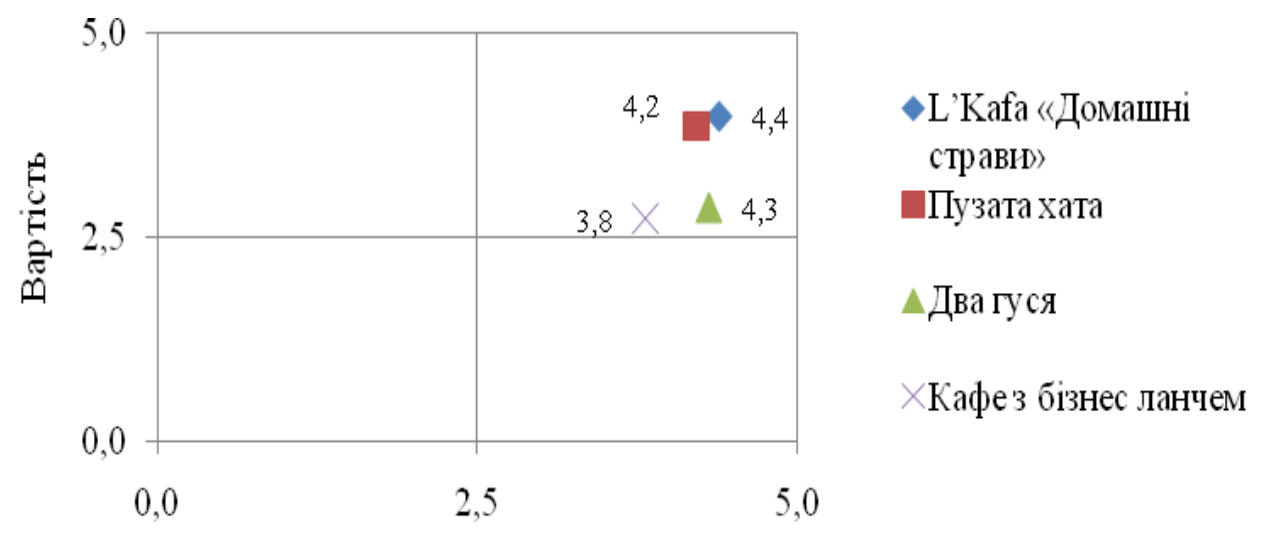

Ситність

Рис. 2. Карта сприйняття «вартість і ситність»

Із попереднього рисунка, робимо висновок, що найбільш ситні страви у «Домашні страви» - 4,4, «Два гуся» $-4,3$, «Пузата хата» $-4,2$, кафе 3 бізнес ланчем - 3,8. 
За допомогою наступної карти сприйняття проаналізуємо залежність вартості і смаку (рис. 3).

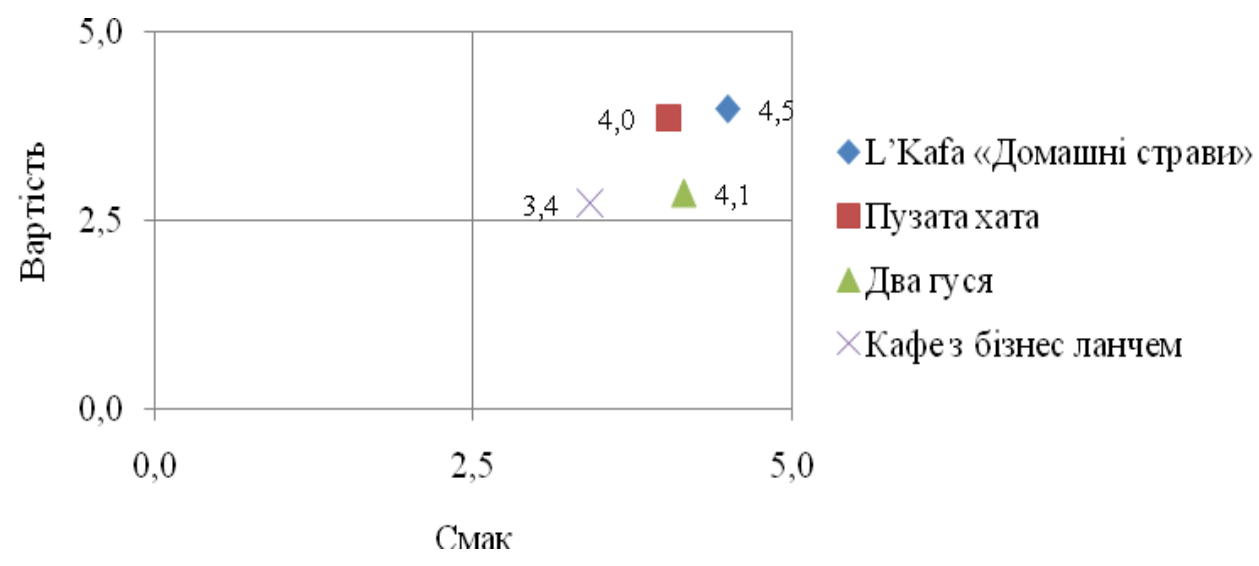

Рис. 3. Карта сприйняття «вартість і смак»

Iз наведеного рисунка, робимо висновок, найкращий смак, на думку респондентів, у закладі «Домашні страви» - 4,5, у «Два гуся» - 4,1, «Пузата хата» - 4,0, кафе з бізнес ланчем - 3,4.

На наступному графіку зображено сприйняття атмосфери відвідувачами закладу (рис. 4).

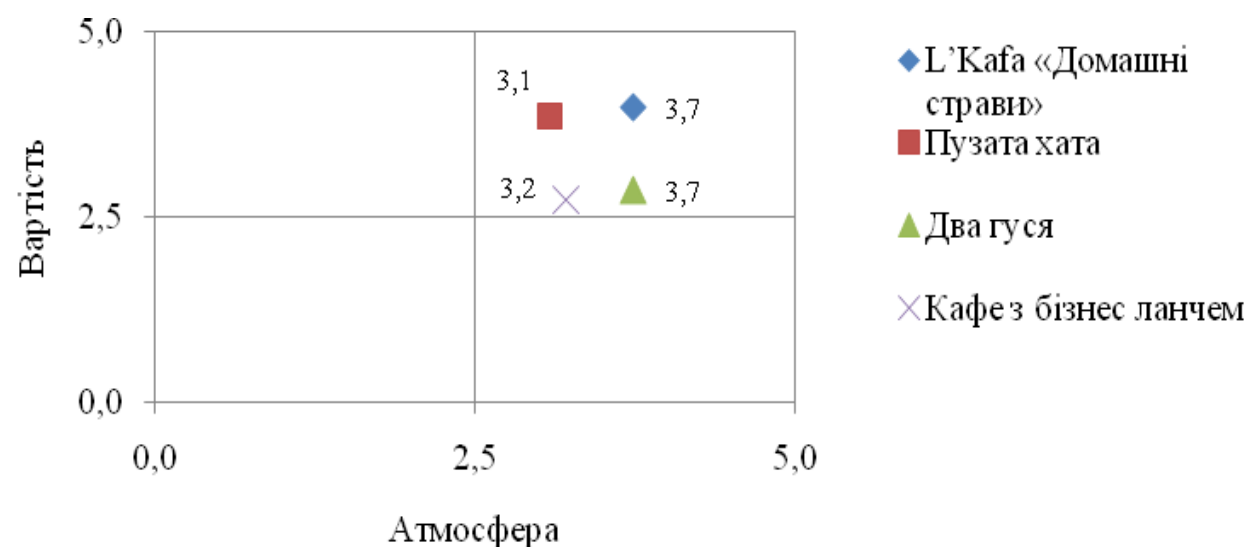

Рис. 4. Карта сприйняття «вартість і атмосфера»

3 наведеної карти випливає, що атмосфера найбільше подобається відвідувачам у «Домашні страви» $\mathrm{i}$ «Два гуся» - 3,7, у кафе з бізнес ланчем 3,2, у «Пузатій хаті» $-3,1$.

Далі проаналізуємо рівень обслуговування у різних закладах (Рис. 5). 


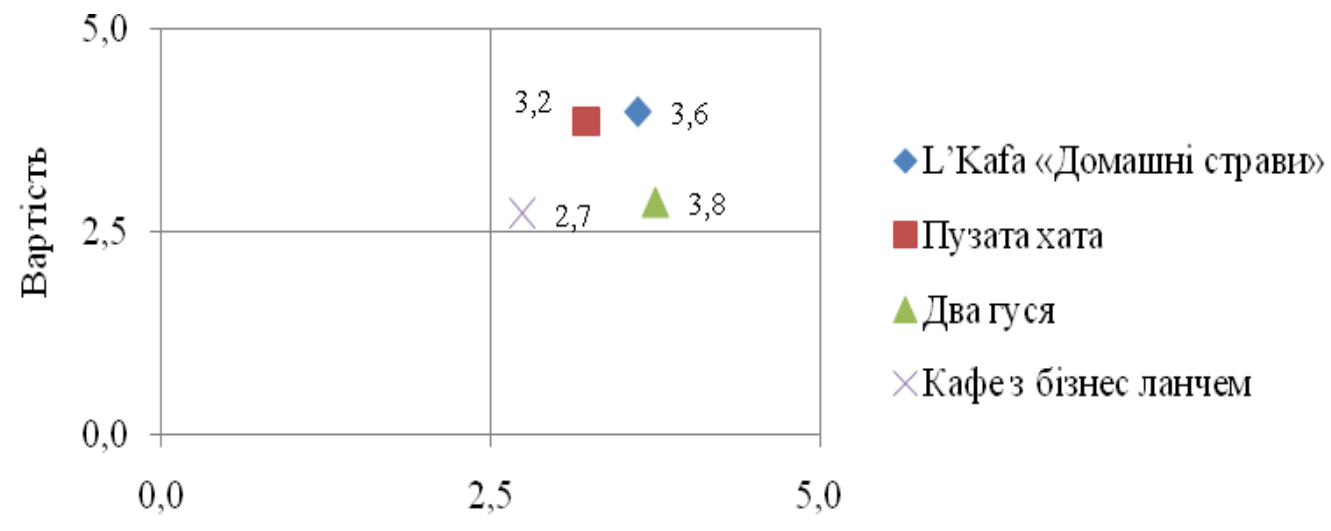

Обслуговування

Рис. 5. Карта сприйняття «вартість і обслуговування»

Найкраще обслуговування відвідувачі оцінюють у закладі «Два гуся» 3,8, у «Домашні страви» - 3,6, у «Пузатій хаті» - 3,2, кафе з бізнес ланчем 2,7 .

Відстань має вагомий вплив під час вибору закладу, тому на наступному рисунку проаналізуємо як респонденти оцінили розташування запропонованих закладів (рис. 6).

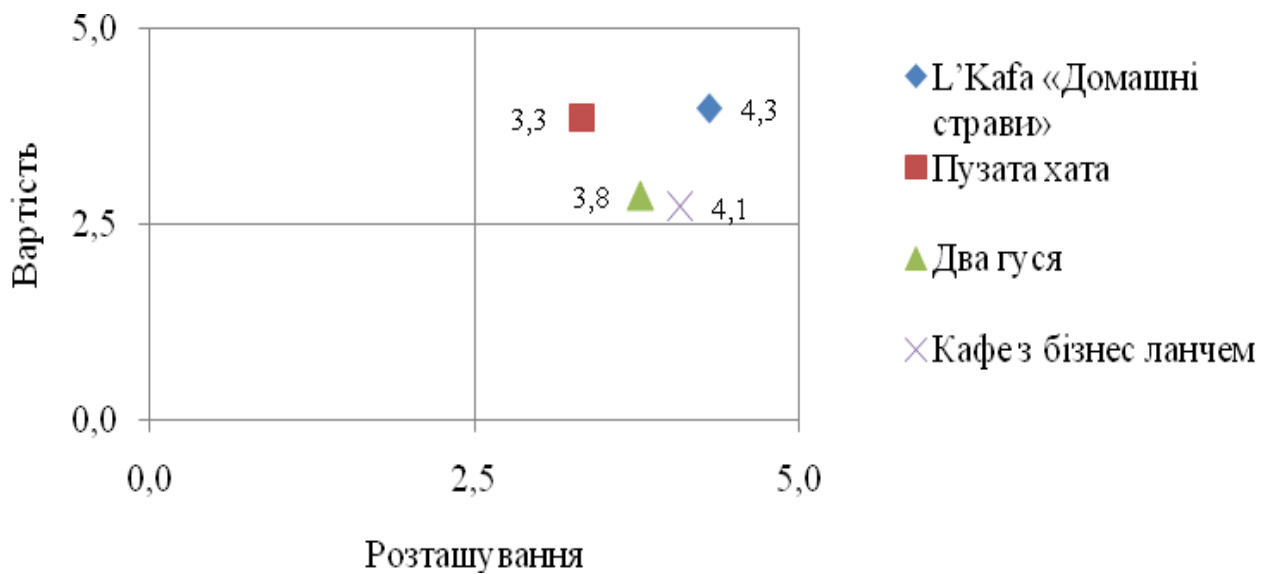

Рис. 6. Карта сприйняття «вартість і розташування»

Із наведеної карти сприйняття, робимо висновок, що найбільш вдале розташування, на думку респондентів, має заклад «Домашні страви» - 4,3, кафе 3 бізнес ланчем - 4,1, «Два гуся» - 3,8, у «Пузатій хаті» - 3,3.

Проаналізувавши карти сприйняття, отримані під час дослідження, найбільш вагомих критеріїв для відвідувачів закладів, отримали інформацію про можливе позиціонування закладів Домашні страви. 3 проаналізованих даних у попередньому пункті, найбільший середній показник порівняно 3 конкурентами отримали наступні параметри (табл. 7) 
Таблиця 7

Обробка карт сприйняття послуг харчування

[за результатами проведенного дослідження]

\begin{tabular}{|c|c|c|c|c|c|c|c|}
\hline Критерії & ДС & ПХ & ДГ & Кафе & Лідер & $\begin{array}{c}\text { Середнє } \\
\text { значення }\end{array}$ & $\begin{array}{c}\text { Відстань } \\
\text { до } \\
\text { середньо } \\
\text { се }\end{array}$ \\
\hline Ціна & 3,59 & 3,87 & 2,87 & 2,73 & Пузата хата & 3,16 & 0,43 \\
\hline Асортимент & 3,58 & 4,18 & 3,58 & 2,93 & Пузата хата & 3,56 & 0,02 \\
\hline Смак & 4,39 & 4,21 & 4,31 & 3,82 & $\begin{array}{c}\text { Домашні } \\
\text { страви }\end{array}$ & 4,11 & 0,27 \\
\hline Ситність & 4,14 & 4,02 & 4,40 & 3,42 & Два гуся & 3,95 & 0,19 \\
\hline Атмосфера & 3,74 & 3,08 & 3,74 & 3,22 & $\begin{array}{c}\text { Два гуся / } \\
\text { Домашні } \\
\text { страви }\end{array}$ & 3,35 & 0,39 \\
\hline Обслуговування & 3,75 & 3,24 & 3,76 & 2,74 & Два Гуся & 3,25 & 0,51 \\
\hline Розташування & 4,30 & 3,32 & 3,77 & 4,07 & $\begin{array}{l}\text { Домашні } \\
\text { страви }\end{array}$ & 3,72 & 0,58 \\
\hline
\end{tabular}

Таким чином, із попередньої таблиці можна зробити висновок, що мережі закладів «Домашні страви» слід позиціонувати себе в першу чергу за тими параметрами за якими споживачі визнали торговельну марку як лідера. Для того щоб оцінити на скільки перевага є значною необхідно розрахувати середні значення за параметрами серед конкурентів після чого розрахувати відстань власної торговельної марки від середнього за кожним параметром. В результаті аналізу карт сприйняття споживачами послуги «Домашні страви» були відібрані наступні параметри які можуть бути використані при позиціонуванні: смак; розміщення.

\section{4. Імплементаційний етап.}

На останньому етапі процесу позиціонування потребують вирішення такі завдання:

- розробка стратегії позиціонування;

- $\quad$ розробка тактики позиціонування.

Перш за все необхідно визначитись із типом позиціонування на основі якого буде розроблено стратегію. В табл. 8 наведена класфікація стратегій позиціонування розроблена Зозульовим О.В. 
Таблиця 8

Классификация стратегий рыночного позиционирования [5]

\begin{tabular}{|c|c|c|c|c|c|c|c|c|}
\hline \multicolumn{9}{|c|}{ Классифікаційні ознаки } \\
\hline $\begin{array}{l}\text { Рівень } \\
\text { позиціо- } \\
\text { нування }\end{array}$ & \begin{tabular}{l|} 
Обьєкт \\
відосно \\
якого \\
прово- \\
диться \\
диференці \\
яція
\end{tabular} & $\begin{array}{l}\text { Віднош } \\
\text { ення до } \\
\text { марок } \\
\text { конку- } \\
\text { рентів }\end{array}$ & $\begin{array}{l}\text { Розташу- } \\
\text { вання в } \\
\text { товарній } \\
\text { категорії }\end{array}$ & $\begin{array}{l}\text { Розташу } \\
\text { вання } \\
\text { віднос- } \\
\text { но } \\
\text { існую- } \\
\text { чих на } \\
\text { ринку } \\
\text { марок }\end{array}$ & $\begin{array}{l}\text { Тип } \\
\text { васти- } \\
\text { востей } \\
\text { товара }\end{array}$ & $\begin{array}{l}\text { Кіль- } \\
\text { кість } \\
\text { обраних } \\
\text { позицій }\end{array}$ & $\begin{array}{l}\text { Стап- } \\
\text { ність } \\
\text { позиціо } \\
\text { нування }\end{array}$ & $\begin{array}{l}\text { Відно- } \\
\text { шення до } \\
\text { існуючої } \\
\text { ринкової } \\
\text { позиції }\end{array}$ \\
\hline \multicolumn{9}{|c|}{ Стратегіï } \\
\hline $\begin{array}{l}\text { - макро } \\
\text { - мезо } \\
\text { - мікро }\end{array}$ & $\begin{array}{l}\text { - } \quad \text { торгової } \\
\text { марки } \\
\text { - } \quad \text { товарної } \\
\text { категоріх }\end{array}$ & $\begin{array}{l}\text { - лідер } \\
\text { - нішер } \\
\text { - клон }\end{array}$ & $\begin{array}{l}\text { - } \quad \text { марка } \\
\text { визначає } \\
\text { товарну } \\
\text { катего- } \\
\text { рію } \\
\text { - марка } \\
\text { визначає } \\
\text { товарну } \\
\text { підка- } \\
\text { тегорію } \\
\text { - марка } \\
\text { спеціа- } \\
\text { ліст }\end{array}$ & $\begin{array}{l}-\quad \text { нова } \\
\text { «відстро } \\
\epsilon \text { на» } \\
\text { марка } \\
-\quad \text { зверх } \\
\text { існую- } \\
\text { чої } \\
\text { марки }\end{array}$ & $\begin{array}{l}\text { - по від- } \\
\text { чутним } \\
\text { властив } \\
\text { остях } \\
\text { - по по } \\
\text { невід- } \\
\text { чутним } \\
\text { властив } \\
\text { остях } \\
\text { - } \quad \text { ка } \\
\text { конкуре } \\
\text { нтним } \\
\text { положе } \\
\text { нням }\end{array}$ & $\begin{array}{l}\text { - уні- } \\
\text { тарне } \\
\text { - много- } \\
\text { мірне }\end{array}$ & $\begin{array}{l}\text { - одно- } \\
\text { етапне } \\
\text { - много- } \\
\text { етапне }\end{array}$ & $\begin{array}{l}\text { - позиціо- } \\
\text { нування } \\
\text { - репо- } \\
\text { зиціонува } \\
\text { ння }\end{array}$ \\
\hline
\end{tabular}

3 огляду на проведений аналіз на попередніх етапах та виходячі із запропонованої класифікації стратугію позиціонування торговельної марки «Домашні страви» можно охарактеризувати наступним чином.

1. Рівень позиціонування: мікро (в описуваному прикладі ми маємо справу з позиціонуванням торговельної марки компанії).

2. Обьєкт відносно якого відбувається диференціювання: торговельна марка.

3. Відношення до марок конкурентів: клон з акцентом на додаткову вигоду.

4. Розміщення відносно існуючих на ринку марок: нова відмінна марка.

5. Тип властивостей на які спирається позиціонування: за відчутними ознаками.

6. Кількість обраних позицій: многофакторне позиціонування (на користь використання саме такої стратегеї говорить той факт, що за результатами аналізу карт сприйняття існує декілька переваг в порівнянні 3 конкурентами).

7. Етапність позиціонування: одноетапне позиціонування. 
8. Стратегія по відношенню до існуючої ринкової позиції: репозиціонування (торговельна марка ыснуэ вже більше шести років на ринку, проте чіткого позиціонування до останнього часу не мала).

Тактика позиціонування передбачає розроблення рекламного звернення. Основою рекламного звернення є слоган, який згідно обраної стратегії та проведеного на попередніх етапах аналізу має концентрувати увагу споживачів на таких параметрах як смак та розташування. Таким чином було сформульовано наступний слоган для мережі закладів під торговельною маркою Домашні страви: «Смачно та поруч з Вами». Для підкріплення ідеї позиціонування макет рекламного звернення має відповідні візуальні образи: якісні зображення основних страв 3 меню та теплі кольори, що викликають апетит. Актуальним засобом для розміщення рекламного звернення $\epsilon$ нарунжна реклама на бігбордах в місцях безпосередньої близькості до закладу швидкого харчування.

Висновки. Наукова новизна даної статті полягає у розвитку теоретичних засад позиціонування, визначено особливості позиціонування ресторанів швидкого обслуговування. Наведено адаптовану до ринку методику позиціонування, яка передбачає чотири етапи: інформаційний, дослідницький, аналітичний та імлементаційний. Практичне значення полягає в апробації методики на прикладі торговельної марки «Домашні страви», для якої в результаті було розроблено стратегію та тактику позиціонування. В статті запропоновано приклад маркетингового дослідження за допомогою якого можливим стає отримання релевантної інформації для розробки стратегії позиціонування.

\section{Література:}

1. Райс Э. Позиционирование: битва за узнаваемость / Э. Райс, Дж. Траут [Пер. с англ. под ред. Ю.Н. Капшуревского]. - Спб: Питер, 2001.

2. Хулей Г. Маркетинговая стратегия и конкурентное позиционирование / Г. Хулей, Дж. Сондерс, Н. Пирси [Пер. С англ.] - Днепропетровск: Баланс Бизнес Букс, 2005.

3. Котлер Ф. Маркетинговий менеджмент: підручник / Ф. Котлер, К.Л. Келлер, А.Ф. Павленко та ін. - К. : «Хімджест», 2008. - 720 с.

4. Аакер Д. Создание сильных брендов / Д. Аакер [Пер. С англ.] - М.: Издательский Дом Гребенникова, 2003. - 340 с.

5. Зозулёв А.В. Стратегии рыночного позиционирования товара на потребительском рынке / А.В. Зозулёв // Отдел маркетинга - 2006. - №11, с 48-53.

6. Зозулев А.В. Рыночное позиционирование: с чего начинается создание успешных брендов / А.В. Зозулев, Н.Л. Писаренко - К.: ЗнаниеПресс, 2004. 
7. Зозульов А.В. Маркетинговые исследования: теория, методология, статистика: учеб. пособие / А.В. Зозулев, С.А. Солнцев. - К.: Знання, 2008. $-643 \mathrm{c}$. 